\title{
Hormones in male sexual development
}

\author{
Serge Nef and Luis F. Parada ${ }^{1}$ \\ Center for Developmental Biology, University of Texas, Southwestern Medical Center, Dallas, Texas 75235-9133, USA
}

A fascinating aspect of development is the potential of sexually undifferentiated embryos to generate male or female individuals. Our knowledge of mammalian sex determination and differentiation has increased steadily in recent years. After presenting a brief overview of gonadal development and sexual determination, this article reviews recent findings concerning male sexual differentiation. In particular, we focus on the three essential hormones secreted by the testes-androgens, MIS, and Insl3-all of which cause male-specific development of the bipotential reproductive system.

In mammals, genetic sex is determined by inheritance of either an $\mathrm{X}$ or $\mathrm{Y}$ chromosome from the male gamete. The initial stages of gonadal and genital development of male and female embryos are indistinguishable by morphological criteria. In females, Müllerian ducts give rise to uterus, fallopian tubes, and proximal vagina, while in males, Wolffian ducts develop into multiple reproductive organs including vas deferens, seminal vesicles, and epididymis. The classic experiment of Jost (Jost 1947; Jost 1953) demonstrated that female differentiation occurs irrespective of the genetic sex in the absence of testicular hormones. Current studies indicate that male differentiation requires the secretion of three testicular hormones. Müllerian-inhibiting substance (MIS), also named Müllerian-inhibiting factor (MIF) or anti-Müllerian hormone $(\mathrm{AMH})$, produced by fetal Sertoli cells induces regression of the Müllerian ducts. Testosterone, produced by Leydig cells, promotes development of Wolffian duct derivatives and masculinization of the external male genitalia. Finally, insulin-like 3 (Insl3) mediates transabdominal testicular descent into the scrotum (Nef and Parada 1999; Zimmermann et al. 1999). In females, differentiation occurs when the absence of MIS allows development of the Müllerian structures, the lack of androgens permits degeneration of Wolffian ducts, and the absence of Insl3 maintains the gonads in the abdomen.

\section{Gonadal and sexual determination}

The gonads originate from thickening of the ventrolateral surface of the embryonic mesonephros called the

\footnotetext{
${ }^{1}$ Corresponding author.

E-MAIL parada@utsw.swmed.edu; FAX (214) 648-1960.

Article and publication are at www.genesdev.org/cgi/doi/10.1101/ gad. 843800 .
}

genital ridge. In mice, the genital ridges are visible at embryonic day 10 (E10) and are composed of somatic cells from the mesonephros and migratory primordial germ cells originated from extraembryonic mesoderm in the yolk sac near the junction of the hindgut and allantois (Ginsburg et al. 1990).

In mammals, four genes are known to be required for development of bipotential gonads (Fig. 1): (a) the orphan nuclear receptor Steroidogenic factor-1 (SF1 or Ftz-F1; for review, see Parker 1998), (b) Wilms tumor-associated gene (WT1; Kreidberg et al. 1993), a zinc finger DNAbinding protein, (c) Lhx1 (also known as Lim1), and (d) Lhx9, two LIM class homeobox proteins (Shawlot and Behringer 1995; Birk et al. 2000). Mice with a homozygous disruption in any one of these genes lack gonads.

Once the gonads are formed, the pivotal event in male sexual differentiation is expression of the $S R Y$ gene (sex determining region of the $\mathrm{Y}$ chromosome). $S R Y$ is necessary and sufficient to initiate the male development cascade (Koopman et al. 1991). SRY encodes a high-mobility group (HMG) box-transcription factor and, similar to other HMG-transcription factors, binds preferentially to a consensus DNA sequence and causes DNA bending (Grosschedl et al. 1994). The physiological target genes for SRY/Sry remain unknown, but potential candidates including Sox9, SF-1, DMRT1, GATA-4, Dhh, and testatin, are up-regulated during testicular differentiation (for review, see Roberts et al. 1999b; Swain and Lovell-Badge 1999). SRY/Sry triggers differentiation of the supporting cell lineage into Sertoli cells (Burgoyne et al. 1988; Palmer and Burgoyne 1991).

The factors produced by Sertoli cells that influence differentiation of the steroidogenic cell lineage into Leydig cells and the germ-cell lineage into prospermatogonias remain unknown. Another major function of Sertoli cells is to sustain germ cells during development and spermatogenesis. They do so by forming tight cell-cell contacts between germ cells and providing factors necessary for growth and differentiation. Factors mediating interaction between Sertoli cells and germ cells act at close range, and one potential candidate is Desert hedgehog (Dhh). Male mutants for Dhh are infertile because of the absence of sperm (Bitgood et al. 1996). Mutant testes show reduced weight from E18.5, and later stages display germ cell deficiency and blockade of spermatogenesis. The early male-specific expression of Dhh, as well as the mutant phenotype, suggests a role in male gonadal differentiation. 


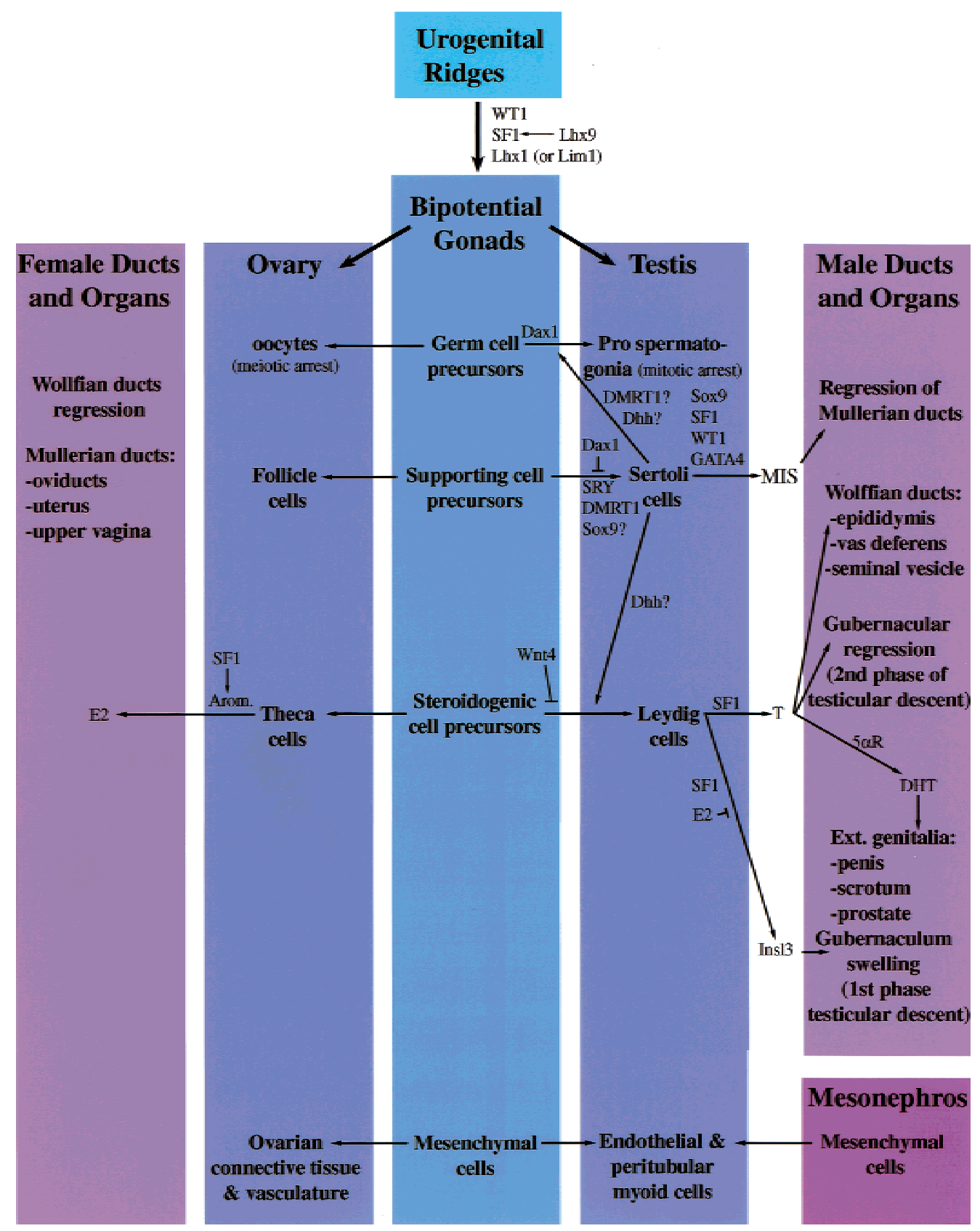

Figure 1. Summary describing known molecular and cellular interactions during gonadal induction, gonadal differentiation, and sexual differentiation. This figure has been adapted from a figure by P. Koopman (Koopman 1999).

$D M R T 1$ is another gene involved in testis differentiation. Humans with hemizygocity for the distal portion of the locus 9p24.3 where DMRT1 has been mapped display defective testicular development and consequent 46, XY feminization (Crocker et al. 1988; Bennett et al. 1993; Raymond et al. 1998). The DMRT1 gene encodes a zinc finger-like DNA-binding protein and is expressed very early in a sex-specific manner in male gonads of all the classes of vertebrates, regardless of the sex-determining mechanism (chromosomal or environmental). In mice, Dmrt1 is expressed in genital ridges of both sexes and then becomes testis specific at the end of the sex-deter- mining period. In testis, Dmrt1 is expressed in germ cells and Sertoli cells (Raymond et al. 1999). Raymond et al. (2000) have recently shown that Dmrt1 is required for testis but not ovarian differentiation. Male mutant mice for Dmrt1 are viable but infertile, with hypoplastic testes, because of disorganized seminiferous tubules and absence of germ cells. Sertoli cell morphology, number, and gene expression are also abnormal. These data indicate that Dmrt1 is necessary for the survival and differentiation of germ cells and Sertoli cells. It will be interesting to determine if germ-cell death in Dmrt1 mutant mice is an autosomous or nonautosomous defect caused 
by a failure of Sertoli cell differentiation. Cell-specific deletion of the Dmrt1 gene in Sertoli cell or germ cells employing the Cre/lox system will provide valuable information concerning this question.

DAX1 has also been implicated in testis differentiation. DAX1 encodes an orphan nuclear receptor and maps to the $\mathrm{X}$ chromosome. In humans, duplication of the DAX1 locus causes male to female sex reversal (Bardoni et al. 1994; Muscatelli et al. 1994; Zanaria et al. 1994) and, for this reason, has been proposed as an ovarian-determining gene (Bardoni et al. 1994). However, XY transgenic mice with multiple copies of Dax1 do not display male-to-female sex reversal. In contrast, XX mice with an Sry transgene fail to initiate testis development in mice carrying multiple copies of Dax1, indicating that Dax1 can antagonize Sry-mediated sex conversion (Swain et al. 1998). Furthermore, in Dax1 mutant mice, ovarian development is not affected, yet spermatogenesis is blocked in the male (Yu et al. 1998). Thus, Dax1 is more likely an "antimaleness" gene rather than an ovarian-determining gene (Parker and Schimmer 1998; Swain et al. 1998; Yu et al. 1998).

\section{Sexual differentiation}

Once gonads have differentiated into testes, the secretion of testicular hormones is sufficient to promote masculinization of the embryo. The male phenotype relies on the secretion of three testicular hormones: MIS, testosterone, and Insl3 (Fig. 1). Following, we will sequentially review recent findings concerning these three testicular hormones.

\section{Müllerian-inhibiting substance}

MIS is a homodimeric glycoprotein linked by disulfide bonds with a molecular weight of $140 \mathrm{kD}$, belonging to the transforming growth factor- $\beta$ (TGF $\beta$ ) superfamily (for review, see Lane and Donahoe 1998). MIS is expressed in fetal and prepubertal Sertoli cells and causes degeneration of the Müllerian ducts. Mutation of the MIS gene or the MIS receptor type II in human males leads to persistent Müllerian duct syndrome (PMDS; Imbeaud et al. 1996; Rey and Picard 1998).

Evidence suggests that MIS causes regression indirectly through its effects on mesenchymal cells surrounding the Müllerian ducts. The MIS type II receptor is expressed in the mesenchyme cells surrounding the Müllerian ducts during the period of sex determination and Müllerian duct regression. Indeed, MIS has no effect on isolated epithelial cells (Tsuji et al. 1992) or on epithelial duct cultured with heterologous mesenchyme lacking the MIS receptor type II (Roberts et al. 1999a). Recently, Allard and colleagues (2000) showed that the cranial to caudal regression of Müllerian ducts correlates with a similar gradient of MIS-receptor II protein in mesenchymal cells followed by a wave of apoptosis in the Müllerian ducts.
MIS signaling is mediated by the single transmembrane-spanning serine/threonine kinase receptors type I and II. The MIS type II receptor binds MIS (Mishina et al. 1999) and then recruits type I receptor to form tetraheteromers. Downstream signaling occurs when receptor I is phosphorylated by the MIS type II receptor. In contrast to MIS receptor type II (Baarends et al. 1994; di Clemente et al. 1994), the type I receptor remains unidentified. Recently, Gouédard and colleagues (2000) provided in vitro evidence that bone morphogenic protein (BMP) type IB receptor (BMPR-IB) interacts with MIS receptor type II in a ligand-dependent manner and transduces signals through the Smadl pathway. Another recent report implicates $\beta$-catenin/LEF1 transduction pathway in mediating MIS action (Allard et al. 2000). In vivo and in vitro MIS application leads to an accumulation of cytoplasmic $\beta$-catenin in mesenchymal cells. Further work will be needed to confirm and clarify the roles played by these different transduction molecules in MIS signaling.

Male Mis gene knockout mice develop as pseudohermaphodites, with retention of Müllerian structures. However, in contrast to humans who exhibit retention of the testes within the abdominal cavity (Josso and di Clemente 1997), mouse testes are normally descended into the scrotum, with infertility being caused by the superimposition of male and female reproductive organs, blocking sperm delivery (Behringer et al. 1994).

MIS is also produced at low levels in adult testes, suggesting a functional role for this hormone in the mature gonad (Tsafriri et al. 1988). Adult transgenic mice chronically overexpressing MIS develop gonadal abnormalities and display reduced serum levels of testosterone levels (Lyet et al. 1995). It is, therefore, not surprising that testosterone-dependent organs such as seminal vesicles, epididymis, and external genitalia are underdeveloped or not virilized. Interestingly, mice mutant for the MIS gene (Behringer et al. 1994) or its type II receptor gene (Mishina et al. 1996) also have gonadal abnormalities consisting of Leydig cell hyperplasia and focal atrophy of the germinal epithelium. This indicates that MIS overexpression might interfere with androgen biosynthesis in Leydig cells. MIS type II receptor gene expression is detected in adult Leydig cells, suggesting that MIS exerts its effect on Leydig cells directly via its receptor (Racine et al. 1998; Teixeira et al. 1999). Indeed, in primary culture of Leydig cells, MIS inhibited LH-stimulated testosterone production (Rouiller-Fabre et al. 1998). In addition, recent data indicate that MIS regulates androgen synthesis directly at the transcriptional level by suppressing the transcription of the P450c17 gene, one of the key enzymes involved in testosterone synthesis (Teixeira et al. 1999). Altogether, these data indicate that MIS has an autocrine/paracrine inhibitory effect on steroidogenesis in the male gonad.

MIS gene regulation has been studied extensively (for review, see Lane and Donahoe 1998). Gene expression begins at $11.5 \mathrm{~d}$ postcoitum $(\mathrm{dpc})$ in mouse gonads, persists through fetal development, and finally decreases after birth (Munsterberg and Lovell-Badge 1991). Several factors implicated in sexual differentiation are required 
for the transcriptional regulation of the Mis gene, including SF-1 (Shen et al. 1994; Giuili et al. 1997), Sox9 (De Santa Barbara et al. 1998), GATA-4 (Viger et al. 1998), and WT-1 (Nachtigal et al. 1998). The proximal $180 \mathrm{bp}$ of the mouse Mis promoter is capable of directing the expression of a reporter gene in primary rat Sertoli cells (Shen et al. 1994) and can recapitulate the normal pattern of Mis expression in transgenic mice (Giuili et al. 1997). Sequence comparison of the 180-bp proximal promoter segment among different mammalian species reveals several conserved motifs, including the characteristic TATA box, an SF-1 binding site, a SOX-binding site, and a putative GATA site (De Santa Barbara et al. 1998; Lane and Donahoe 1998). SOX9 can bind the canonical SOXbinding site and interact with SF-1 for a cooperative activation of MIS (De Santa Barbara et al. 1998). Recently, male mice homozygous for a mutant Sox9-binding site have been generated (Arango et al. 1999). These mutant mice do not initiate Mis transcription, resulting in the persistence of Müllerian structures and pseudohermaphrodism. These data strongly suggest that Sox 9 is essential for the initiation of Mis transcription.

A conserved 20-bp binding site for SF-1 is present in the 180-bp MIS proximal promoter. SF-1 expression begins at $9 \mathrm{dpc}$ in the genital ridges of both sexes but is up-regulated in males and down-regulated in females as sexual differentiation proceeds (Ikeda et al. 1994). It has been shown that SF-1 activates transcription of the MIS promoter in heterologous cell lines (Shen et al. 1994; Nachtigal et al. 1998). Finally, XY individuals with a heterozygous mutation in the SF-1 DNA-binding domain undergo complete XY sex reversal, including normal female external genitalia, streak gonads, retention of the uterus, and Müllerian structures, thus indicating the importance of SF-1 in testis determination and MIS gene regulation (Achermann et al. 1999). Interestingly, in vivo mutation of the proximal SF-1-binding site in mice is not essential for Müllerian duct regression and results in correct initiation of Mis transcription, although at significantly reduced levels (Arango et al. 1999). In vivo studies have characterized a second, more distal SF-1 binding site essential for full activity of the human MIS promoter (Watanabe et al. 2000). Mutational analysis has confirmed that both the distal and proximal SF-1 binding sites are required for full activity of the MIS promoter. These results could explain the failure of the proximal SF-1 binding-site mutant mice to completely abolish Mis expression and the persistence of Müllerian ducts.

Yet another factor involved in the regulation of Mis expression is WT1. Although WT1 does not bind the Mis promoter, it interacts physically with SF-1 and synergistically up-regulates Mis transcription in vitro (Nachtigal et al. 1998). In contrast, Dax-1 antagonizes the functional interaction between SF-1 and WT1, suggesting that it may account for the activation or repression of male-specific genes (Nachtigal et al. 1998). Finally, GATA4 may also have a role in the control of MIS expression through binding of the conserved proximal and distal GATA sites (Viger et al. 1998; Watanabe et al. 2000).

\section{Steroid hormones}

Secretion of androgens by Leydig cells is essential for masculinization of the fetus. Steroid synthesis takes place within the mitochondria of Leydig cells. The enzymatic steps leading to the synthesis of testosterone from cholesterol involve the steroidogenic acute regulatory protein (StAR), a transporter of cholesterol through the inner mitochondrial membrane and specific enzymes, including cytochrome P450 side-chain cleavage (P450scc), P450c17, and 3 $\beta$-hydroxysteroid deshydrogenase ( $3 \beta$-HSD). Testosterone is crucial for survival of the Wolffian duct, as well as for its differentiation into epididymis, ductus deferens, and seminal vesicle.

Testosterone also serves as a substrate for two metabolic pathways that produce antagonistic sex steroids. On the one hand, testosterone can be reduced by $5 \alpha$ reductase to produce $5 \alpha$ dihydrotestosterone (DHT). On the other hand, testosterone can be aromatized to generate estrogens. DHT and estrogens have opposite effectswhile androgens virilize, estrogens feminize. Therefore, the synthesis of each of these steroid hormones in males and females must be subject to regulation that maintains a delicate balance between testicular androgens and estrogens. This can be achieved by establishing an appropriate amount of testosterone (or androstenedione) conversion into either DHT or estradiol.

Testosterone and DHT bind to the same androgen receptor (AR), while estradiol binds two estrogen receptors $\mathrm{ER} \alpha$ and $\operatorname{ER} \beta$. These steroid family receptors are hormone-activated DNA-binding transcription factors for targeted genes that will mediate the androgen or estrogen response (for review, see Couse and Korach 1999).

DHT mediates differentiation and development of male urogenital structures. The conversion of testosterone to DHT is catalyzed in peripheral target tissues. DHT is converted by two $5 \alpha$ reductase enzymes (type I and II), with $5 \alpha$ reductase type $I$ being expressed in the skin and liver (Thigpen et al. 1993), while the type II isoenzyme is expressed in the urogenital tract and the liver. A role for the type I isozyme in sexual differentiation has not been demonstrated, but it does seem to be required for the reduction of androgens levels, which in turn inhibit the excess formation of estrogens. Mutant mice for the type I isozyme gene fail to deliver normalsize litters because of high levels of estrogens, which cause fetal death during midgestation (Mahendroo et al. 1997). No mutation of the type I enzyme gene has yet been identified in humans, probably because it is masked by the presence of normal type II enzyme. In contrast, patients with mutation in the type II isoenzyme exhibit male pseudohermaphroditism (Can et al. 1998).

Estrogens and male fertility A role for estrogens in testicular function and spermatogenesis remained elusive until the generation of mutant mice for the aromatase gene or the estrogen receptors $\alpha$ and $\beta$ (ER $\alpha$ and ER $\beta$, respectively). $\alpha$ ERKO, $\beta E R K O$, or $\alpha \beta E R K O$ male mice exhibit normal internal and external sexual structures that are indistinguishable from wild-type littermates, 
thus indicating that estrogens are not necessary for gonad development or for the male urogenital structures. However, $\alpha$ ERKO male mice are sterile because of pleiotropic defects that include abnormal sexual behavior as well as reduction in number $(80 \%)$ and motility $(5 \%)$ of epididymal sperm (Eddy et al. 1996; Ogawa et al. 1997). In contrast, $\beta E R K O$ males exhibit normal fertility and sperm counts (Couse and Korach 1999), and double-mutant male mice exhibit a phenotype similar to the $\alpha$ ERKO mice (Couse et al. 1999). The $\alpha \beta E R K O$ testicular phenotype is different from mutant mice lacking the aromatase gene, which display arrested spermatogenesis (Robertson et al. 1999). This suggests a direct action of estrogen on male germ-cell development and fertility. The difference in phenotype between mice lacking estradiol and mice lacking both $\alpha$ and $\beta$ ERs suggests the existence of either an additional aromatase, an undocumented ER, or an estradiol-independent ER action in the male urogenital system (Couse et al. 1999).

Wnt4 Recently, it has been shown that Wnt4, a member of the Wnt gene family, plays a key role in female sexual differentiation by controlling steroidogenesis in the gonad (Vainio et al. 1999). During sex-specific differentiation of the gonads around E11.5, Wnt4 expression is down-regulated in male gonads but maintained in female gonads. In female mutant mice, the absence of Wnt4 signaling in developing ovaries ectopically initiates steroidogenesis. This suggests that Wnt4 is able to suppress the development of the Leydig cells in the ovary. In addition to its effect on regulating steroidogenesis, Wnt4 is also implicated in the formation of the Müllerian duct, as well as possibly being required for maintenance of the female germ line.

\section{Testicular descent}

In addition to Müllerian duct regression and androgendependent virilization of the urogenital system, transfer of the male gonad from its site of origin at the urogenital ridge, apposed to the kidney, into the scrotum is yet another critical event in male sexual differentiation. In humans, failure of complete testicular descent into the scrotum (cryptorchidism) is one of the most frequent congenital abnormalities involving $\sim 3 \%$ of male births. At 1 yr of age, $1 \%$ of infants still have undescended testes (Hutson et al. 1994). Cryptorchidism is a clinical issue for two reasons. First, spermatogenesis requires a lower temperature present in the scrotum. Untreated cryptorchidism can lead to infertility. In addition, cryptorchidism is associated with an increased risk of testicular tumors (Hutson et al. 1994).

The genital mesentery, composed of the cranial suspensory ligaments (CSL) and the caudally positioned gubernaculum, connects the gonads to the abdominal wall. In mice, sexually dimorphic development of the genital mesentery is responsible for the sexually dimorphic position of mature testes and ovaries (Fig. 2). In the female embryo, development of the CSL but not of the gubernaculum maintains the ovaries at the original position of the gonads. In contrast, in the male embryo, regression of the CSL and the outgrowth and subsequent regression and inversion of the gubernaculum mediates transfer of the testes into the scrotum.

Testicular descent occurs in two morphologically distinct, hormonally regulated phases (Hutson et al. 1994). During the transabdominal phase $(15.5-17.5 \mathrm{dpc}$ in mice), the testes relocate from the original high abdominal position to the base of the abdomen. The gubernaculum, first described by John Hunter 250 yr ago (Hunter $1762)$, is a mesenchymal tissue that connects the urogenital ridge to the inguinal abdominal wall and contributes to the transabdominal descent. Gubernacular development is sexually dimorphic. In females, while gubernacular attachment to the gonad occurs, it remains a thin, flexible chord that passively elongates with embryonic growth. In contrast, male rodent embryos undergo contraction of the gubernacular cord and outgrowth of the gubernacular bulb concomitant with the elongation of the embryonic rostro-caudal axis, placing the testes at the base of the abdomen at birth. The second phase of testicular descent, the inguino-scrotal phase, corresponds to the migration of the testes and epididymis through the inguinal canal into the scrotum.



Figure 2. Schematic drawing describing the first phase of testicular descent in mice. In males, the presence of testosterone induces regression of the cranial suspensory ligaments (CSL), while Insl3 promotes contraction of the gubernacular cord and outgrowth of the gubernacular bulb. These morphological changes in the genital ligament allow the testes to relocate at the base of the abdominal cavity. In females, the absence of testosterone allows the CSL to develop and retain the ovaries at their original position, while the gubernaculum elongates and does not develop because of the absence of Insl3. 


\section{Transabdominal descent}

The factor promoting transabdominal testicular descent via contraction and outgrowth of the gubernaculum has been speculated on and sought after for decades. Various studies have established that gubernacular outgrowth does not require androgens, as it occurs normally in humans or animals with androgen deficiency or resistance (Griffin and Wilson 1980). Castration experiments carried out during testicular descent have shown that the presence of testes is required for outgrowth of the gubernaculum (Wensing 1988). In addition, proliferation of gubernacular cells in pigs is induced only by fetal and adult testicular extract, a phenomenon that can not be reproduced by several growth factors including MIS, inhibin, or androgens (Visser and Heyns 1995). Mice mutant for the Mis gene or its receptor exhibit normal testicular descent and normal outgrowth of the gubernaculum (Behringer et al. 1994; Mishina et al. 1996). Moreover, targeted deletion studies in mice have identified insulin-3 (Insl3) as a factor crucial for transabdominal descent (Nef and Parada 1999; Zimmermann et al. 1999).

\section{Ins13}

The Insulin-3 gene, also known as Leydig insulin-like hormone (Ley I-L) or relaxin-like factor (RLF) is a member of the insulin peptide hormone family (Adham et al. 1993; Pusch et al. 1996; Zimmermann et al. 1997). Recent studies have shown that the family includes at least eight members: insulin, relaxin, insulin-like growth factors I and II, insulin-like 3, and the recently identified members insulin-like 4 (Ins14 or EPIL; Chassin et al. 1995), insulin-like 5 (Ins15; Conklin et al. 1999) or RIF-2 (Hsu 1999), and insulin-like 6 (Ins16; Kasik et al. 2000; Lok et al. 2000) or RIF-1 (Hsu 1999). The mature Insl3 hormone, like insulin, is composed of A and B chains linked by disulfide bonds (Adham et al. 1993). Although comparison between all members of the family reveals relatively low sequence homology $(20 \%-40 \%$ identity at the amino acid level in A and B chains), the six cysteines needed for disulfide bridge formation and proper folding of insulin and insulin-related polypeptides are completely conserved. Ins13 expression reveals sexual dimorphism (Zimmermann et al. 1997; Balvers et al. 1998). In male mice, Ins13 transcripts are first detected at E13.5 in Leydig cells and remain constant through the third week of postnatal life, when increases are observed coincident with the first wave of spermatogenesis and germ-cell maturation. In females, Ins13 transcripts are first detected at P6 in theca cells of the ovary (Zimmermann et al. 1997). In human ovaries, Ins13 transcripts have been detected in the theca interna cells at a lower level in the corpus luteum (Bamberger et al. 1999).

Ins13 mutant mice are viable, but males exhibit bilateral cryptorchidism caused by developmental abnormalities of the gubernaculum (Nef and Parada 1999; Zimmermann et al. 1999). Ins13-/- male gubernaculae do not develop but do form a long, thin elongated structure similar to normal female gubernaculae (Fig. 3). Micro- scopic analysis of the Ins13-/- gubernaculum reveals some muscle development but no mesenchymal core with a very thin and elongated cord (J.M. Hustson, pers. comm.). In contrast, normal male gubernaculae exhibit a contracted gubernacular cord and a swollen gubernacular bulb. The testes of mutant animals are freely moving within the abdominal cavity, and in some cases, one testis is located on the opposite side of the abdomen (crossed ectopia with torsion of the vas deferens).

Since androgens have been shown to mediate the second phase of testicular descent, the androgen status of Ins13 mutant mice was investigated. In contrast to other models of cryptorchidism caused either by testosterone insensitivity (Fig. 4), such as in the testicular feminization mice (Tfm), which contain a mutation in the androgen receptor gene (Lyon and Hawkes 1970), or testosterone deficiency such as the gonadotrophin-releasing hormone (GnRH)-deficient mice (Radovick et al. 1991), Ins13-/- males exhibit virile, androgen-dependent behavior including normal mounting and copulatory behavior (Nef and Parada 1999; Zimmermann et al. 1999). Moreover, the development of male accessory organs such as the seminal vesicles and prostate, which are greatly reduced in androgen-deficient males (Wilson et al. 1981), is unaffected in Ins13 mutant males. Finally, serum testosterone levels are similar in WT and Ins13-/adult males. Taken together, these behavioral, anatomical, and hormonal features indicate that deficiency in intrabdominal descent in Ins13-/- males cannot be attributed to androgen deficiency.

There exist significant anatomical and hormonal differences among the different animal models used to study testicular descent-particularly regarding the composition of the gubernaculum. In rodents, the gubernaculum is mainly composed of cremasteric muscle with a mesenchymal core. This differs from human, pig, or dog, where gubernaculum is composed predominantly of a mesenchymal, muco-polysaccharide structure with minor muscular component. Interestingly, Insl3 is necessary for development of the mesenchymal core of the gubernaculum but not of the cremasteric muscle (J.M. Hustson, pers. comm.). Because the effect of Insl3 is directed at the mesenchymal component of the gubernaculum, it is possible that Insl3 is also implicated in the transabdominal decent of testis in humans. However, the role of Insl3 hormone in human testicular descent remains to be confirmed.

\section{Ins13 and fertility}

In males, Ins13 expression increases dramatically during puberty (Zimmermann et al. 1997), which suggests an additional role for this hormone in male fertility. Testes in Ins13-/- mice have normal morphology and histology at birth but display impaired spermatogenesis in adults because of increased environmental temperature resulting from the intrabdominal position of the mutant testes. In an experiment performed with Ins13-/- mice, where the testes were surgically descended at $3 \mathrm{wk}$ of age (orchiopexy), normal spermatogenesis was observed in 

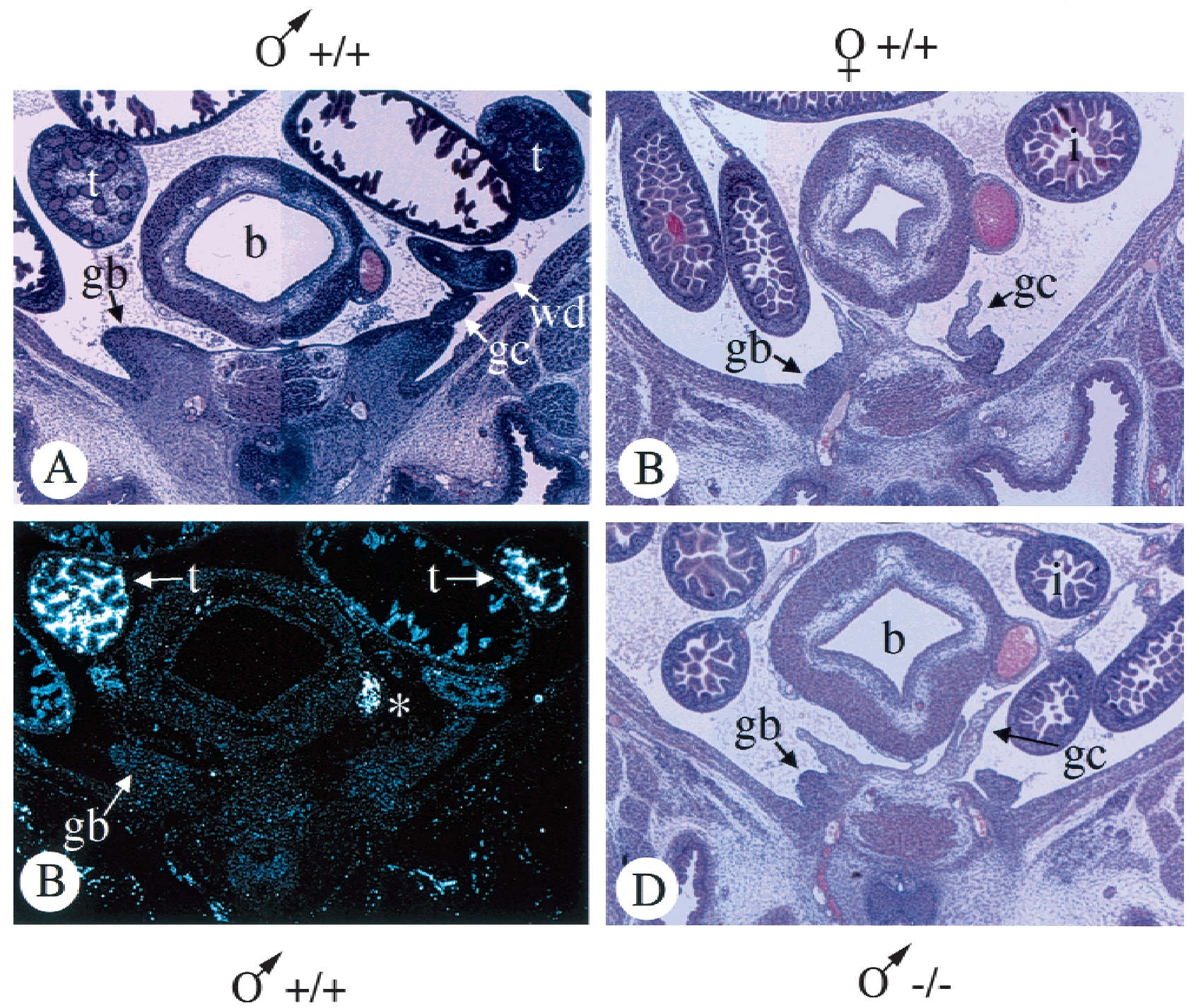

Figure 3. Feminized gubernacula in Insl3-/- male mice. Histological sections at embryonic day 16.5 (E16.5) in (a) wild-type male display a contracted gubernacular cord and swollen gubernaculum with descended testes. In contrast, mutant male (d) or wild-type female $(b)$ show a thin, elongated undeveloped gubernaculum. (c) Dark field picture of a wild-type male adjacent section hybridized with an antisense probe for Insl3. Insl3 transcripts are present only in the testes. The white spot in the center of the image (asterix) is refraction of red blood cells in the abdominal aorta. b, bladder; gb, gubernaculum; gc, gubernaculum cord; t, testis; wd, wolfian duct. Reprinted with the permission of Nature Genetics.

mutant males despite sterility, which was attributed to anatomical alteration of the urogenital system during the operation (Zimmermann et al. 1999). Therefore, Insl3 is not essential for spermatogenesis, but its potential role(s) in male fertility remains to be clarified.

\section{Ins13 and estrogens}

In human, several observations have led to the hypothesis that exposure to a high level of estrogen during early pregnancy may be related to cryptorchidism. Treatment of pregnant women with the nonsteroidal synthetic estrogen diethylstilbestrol (DES) is associated with cryptorchidism in male offspring (Gill et al. 1979). Bernstein and colleagues (1988) have reported that mothers of children with cryptorchidism had significantly higher levels of free estradiol during the first trimester when compared with mothers whose offspring had normally descended testes.

In rodents, the classical experimental model for intraabdominal cryptorchidism is produced by exposing pregnant female to exogenous estrogens (Greene et al. 1942; Grocock et al. 1988). The effects of estradiol include reduction of gubernacular outgrowth, induction of estrogen receptors within Wolffian ducts, and stabilization of Müllerian ducts.

The observation that both the absence of Insl3 hormone and in utero exposure to exogenous estrogen induce bilateral cryptorchidism in newborn males has trig- 
Figure 4. Schematic drawing representing the different positions of maldescended testes. Mutant or treated mice affecting the Insl3-mediated transabdominal descent or the androgen-mediated inguino-scrotal descent are labeled accordingly.

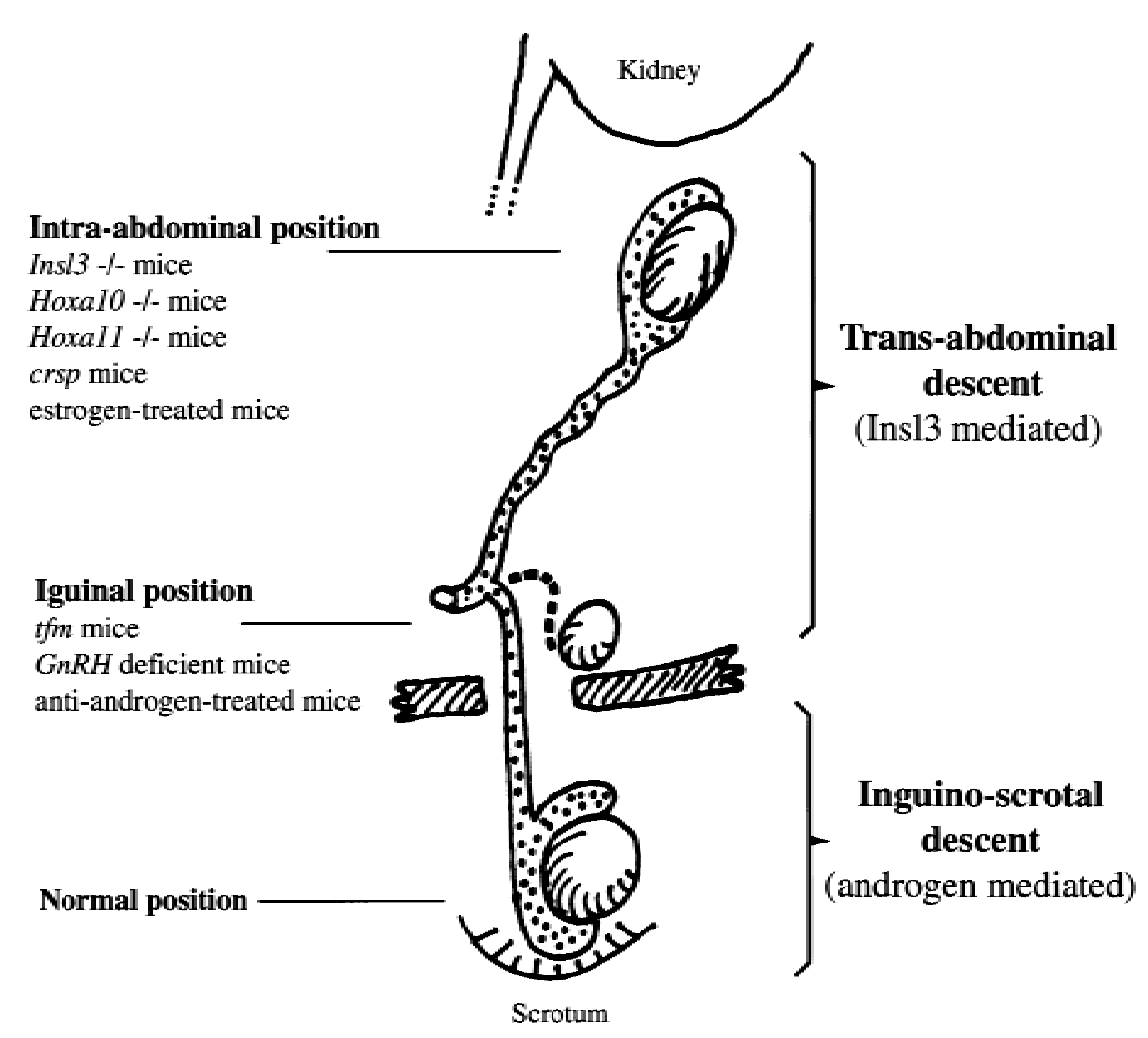

identified for a third RTK, insulin receptor-related receptor (IRR; Shier and Watt 1989; Kelly-Spratt et al. 1999). Ligand-binding studies with iodinated Insl3 reveal specific high-affinity binding with a single subunit receptor of $>200 \mathrm{kD}$ (Bullesbach and Schwabe 1999). This potential Insl3 receptor is clearly different from the IR, IRR, and IGFR1 multisubunit receptor of $>300 \mathrm{kD}$. These preliminary data indicate that the Insl3 receptor may not belong to the RTK family.

Recently, a transgenic insertion mutant mouse strain called crsp (cryptorchidism with white spotting) that exhibits a phenotype strikingly similar to Insl3 mutants has been generated (A.I. Agoulnik, pers. comm.). Males homozygous for the crsp transgene insertion have bilateral intraabdominal cryptorchidism. Surgical descent of the mutant testes in the scrotum reveal the presence of sperm in the epididymis, indicating that crsp is, like Insl3, not essential for spermatogenesis. The crsp locus has been localized to the immediate proximity of the mouse Brca2 locus, which corresponds to the 13q12-13 region in the human chromosome. The similar phenotype shared between Ins13 and crsp mutant mice suggests that both are implicated in the same signal transduction pathway. Identification of the crsp candidate gene may provide useful information concerning Insl3 signaling.

\section{Testicular descent and Hox genes}

Hox genes are involved in specifying regional identity of the developing body. The Hoxa-10 and Hoxa-11 genes 
are both coexpressed in reproductive tracts. Male mice mutant for Hoxa-10, Hoxa-11, or Hoxa-10/Hoxa-11 transheterozygous exhibit unilateral or bilateral cryptorchidism caused by reproductive tract anteriorization, causing developmental abnormalities of the gubernaculum (Hsieh-Li et al. 1995; Rijli et al. 1995; Satokata et al. 1995; Branford et al. 2000). We believe that the mutant gubernaculae lack the capability to transduce or implement Insl3 signaling-perhaps through lack of induction of the physiological receptor-which leads to undeveloped gubernaculae typically found in females.

\section{Hormonal control of inguino-scrotal descent}

The final phase of testicular descent, the inguino-scrotal descent, is regulated by a combination of hormonal and mechanical factors. During the transabdominal phase, the enlarged gubernaculum holds the testis close to the inguinal canal. Then androgens induce gubernacular regression by disappearance of the extracellular matrix leading to a condensation of fibrous material and an increase in cell density (Heyns and de Klerk 1985). It is hypothesized that the combination of regression of the gubernaculum and abdominal pressure caused by the growth of viscera, push the testes down through the inguinal canal (Frey et al. 1983). Inguino-scrotal descent is similar in humans and rodents, but the timing differs. In humans, the inguinoscrotal phase starts around week 26 of gestation. The gubernaculum reaches the scrotum at $\sim 35 \mathrm{wk}$. In contrast, regression of the gubernaculum in rodents happens close to birth just before inguinoscrotal migration (Wensing 1986).

Androgens act as paracrine factors controlling this final phase of testicular descent, as it is absent in humans or animals with androgen resistance (Hutson 1986) or experimentally when androgen deficiency is elicited by prenatal blockade with antiandrogens (Husmann and McPhaul 1991; see Fig. 4). The gubernaculum contains high levels of androgen receptor (Bentvelsen and George 1993) and is considered the primary site of androgen action in testicular descent. In fact, gubernacular regression does not take place in testicular feminized males (Hutson 1985). Currently, it is hypothesized that androgens alter the viscoelastic properties of the gubernaculum, thereby allowing intraabdominal pressure to push the testes into the scrotum (Husmann and Levy 1995).

\section{Summary}

Classical embryology has provided a clear view of the timing and hormonal cues that govern sexual differentiation. Molecular biology has added important details to this picture. The cloning of SRY, MIS, and INSL3 provide insight into the molecular signals that provide important cues at the cellular level. Continued understanding of these pathways may provide the necessary information to one day reverse defects of sexual differentiation.

\section{Acknowledgments}

We apologize to those authors whose work has not been cited because of space limitations. We are grateful to Keith Parker and Richard Behringer for critical review of the manuscript. We thank J. Hutson for sharing insights and unpublished results. The authors were supported by an Excellence in Education Grant to L.F.P.

\section{References}

Achermann, J.C., Ito, M., Hindmarsh, P.C., and Jameson, J.L. 1999. A mutation in the gene encoding steroidogenic factor- 1 causes XY sex reversal and adrenal failure in humans. Nat. Genet. 22: 125-126.

Adham, I.M., Burkhardt, E., Benahmed, M., and Engel, W. 1993. Cloning of a cDNA for a novel insulin-like peptide of the testicular Leydig cells. J. Biol. Chem. 268: 26668-26672.

Allard, S., Adin, P., Gouedard, L., di Clemente, N., Josso, N., Orgebin-Crist, M.C., Picard, J.Y., and Xavier, F. 2000. Molecular mechanisms of hormone-mediated Müllerian duct regression: Involvement of $\beta$-catenin. Development 127: 3349-3360.

Arango, N.A., Lovell-Badge, R., and Behringer, R.R. 1999. Targeted mutagenesis of the endogenous mouse Mis gene promoter: In vivo definition of genetic pathways of vertebrate sexual development. Cell 99: 409-419.

Baarends, W.M., van Helmond, M.J., Post, M., van der Schoot, P.J., Hoogerbrugge, J.W., de Winter, J.P., Uilenbroek, J.T., Karels, B., Wilming, L.G., Meijers, J.H., et al. 1994. A novel member of the transmembrane serine/threonine kinase receptor family is specifically expressed in the gonads and in mesenchymal cells adjacent to the mullerian duct. Development 120: 189-197.

Balvers, M., Spiess, A.N., Domagalski, R., Hunt, N., Kilic, E., Mukhopadhyay, A.K., Hanks, E., Charlton, H.M., and Ivell, R. 1998. Relaxin-like factor expression as a marker of differentiation in the mouse testis and ovary. Endocrinology 139: 2960-2970.

Bamberger, A.M., Ivell, R., Balvers, M., Kelp, B., Bamberger, C.M., Riethdorf, L., and Loning, T. 1999. Relaxin-like factor (RLF): A new specific marker for Leydig cells in the ovary. Int. J. Gynecol. Pathol. 18: 163-168.

Bardoni, B., Zanaria, E., Guioli, S., Floridia, G., Worley, K.C., Tonini, G., Ferrante, E., Chiumello, G., McCabe, E.R., Fraccaro, M., et al. 1994. A dosage sensitive locus at chromosome $\mathrm{Xp} 21$ is involved in male to female sex reversal. Nat. Genet. 7: 497-501.

Behringer, R.R., Finegold, M.J., and Cate, R.L. 1994. Müllerianinhibiting substance function during mammalian sexual development. Cell 79: 415-425.

Bennett, C.P., Docherty, Z., Robb, S.A., Ramani, P., Hawkins, J.R., and Grant, D. 1993. Deletion 9p and sex reversal. J. Med. Genet. 30: 518-520.

Bentvelsen, F.M. and George, F.W. 1993. The fetal rat gubernaculum contains higher levels of androgen receptor than does the postnatal gubernaculum. J. Urol. 150: 1564-1566.

Bernstein, L., Pike, M.C., Depue, R.H., Ross, R.K., Moore, J.W., and Henderson, B.E. 1988. Maternal hormone levels in early gestation of cryptorchid males: A case-control study. Br. J. Cancer 58: 379-381.

Birk, O.S., Casiano, D.E., Wassif, C.A., Cogliati, T., Zhao, L., Zhao, Y., Grinberg, A., Huang, S., Kreidberg, J.A., Parker, K.L., et al. 2000. The LIM homeobox gene Lhx9 is essential for mouse gonad formation. Nature 403: 909-913.

Bitgood, M.J., Shen, L., and McMahon, A.P. 1996. Sertoli cell signaling by Desert hedgehog regulates the male germline. Curr. Biol. 6: 298-304.

Branford, W.W., Benson, G.V., Ma, L., Maas, R.L., and Potter, 
S.S. 2000. Characterization of Hoxa-10/Hoxa-11 transheterozygotes reveals functional redundancy and regulatory interactions. Dev. Biol. 224: 373-387.

Bullesbach, E.E. and Schwabe, C. 1999. Specific, high affinity relaxin-like factor receptors. J. Biol. Chem. 274: 2235422358.

Burgoyne, P.S., Buehr, M., Koopman, P., Rossant, J., and McLaren, A. 1988. Cell-autonomous action of the testis-determining gene: Sertoli cells are exclusively XY in XX--.-XY chimaeric mouse testes. Development 102: 443-450.

Can, S., Zhu, Y.S., Cai, L.Q., Ling, Q., Katz, M.D., Akgun, S., Shackleton, C.H., and Imperato-McGinley, J. 1998. The identification of $5 \alpha$-reductase- 2 and $17 \beta$-hydroxysteroid dehydrogenase- 3 gene defects in male pseudohermaphrodites from a Turkish kindred. J. Clin. Endocrinol. Metabol. 83: $560-569$.

Chassin, D., Laurent, A., Janneau, J.L., Berger, R., and Bellet, D. 1995. Cloning of a new member of the insulin gene superfamily (INSL4) expressed in human placenta. Genomics 29: 465-470.

Conklin, D., Lofton-Day, C.E., Haldeman, B.A., Ching, A., Whitmore, T.E., Lok, S., and Jaspers, S. 1999. Identification of INSL5, a new member of the insulin superfamily. Genomics 60: 50-56.

Couse, J.F. and Korach, K.S. 1999. Estrogen receptor null mice: What have we learned and where will they lead us? Endocr. Rev. 20: 358-417.

Couse, J.F., Hewitt, S.C., Bunch, D.O., Sar, M., Walker, V.R., Davis, B.J., and Korach, K.S. 1999. Postnatal sex reversal of the ovaries in mice lacking estrogen receptors $\alpha$ and $\beta$. Science 286: 2328-2331.

Crocker, M., Coghill, S.B., and Cortinho, R. 1988. An unbalanced autosomal translocation $(7 ; 9)$ associated with feminization. Clin. Genet. 34: 70-73.

De Santa Barbara, P., Bonneaud, N., Boizet, B., Desclozeaux, M., Moniot, B., Sudbeck, P., Scherer, G., Poulat, F., and Berta, P. 1998. Direct interaction of SRY-related protein SOX9 and steroidogenic factor 1 regulates transcription of the human anti-Müllerian hormone gene. Mol. Cell. Biol. 18: 6653-6665.

di Clemente, N., Wilson, C., Faure, E., Boussin, L., Carmillo, P., Tizard, R., Picard, J.Y., Vigier, B., Josso, N., and Cate, R. 1994. Cloning, expression, and alternative splicing of the receptor for anti-Müllerian hormone. Mol. Endocrinol. 8: 1006-1020.

Eddy, E.M., Washburn, T.F., Bunch, D.O., Goulding, E.H., Gladen, B.C., Lubahn, D.B., and Korach, K.S. 1996. Targeted disruption of the estrogen receptor gene in male mice causes alteration of spermatogenesis and infertility. Endocrinology 137: 4796-4805.

Emmen, J.M., McLuskey, A., Adham, I.M., Engel, W., VerhoefPost, M., Themmen, A.P., Grootegoed, J.A., and Brinkmann, A.O. 2000. Involvement of insulin-like factor 3 (Insl3) in diethylstilbestrol-induced cryptorchidism. Endocrinology 141: 846-849.

Frey, H.L., Peng, S., and Rajfer, J. 1983. Synergy of abdominal pressure and androgens in testicular descent. Biol. Reprod. 29: 1233-1239.

Gill, W.B., Schumacher, G.F., Bibbo, M., Straus, F.D., and Schoenberg, H.W. 1979. Association of diethylstilbestrol exposure in utero with cryptorchidism, testicular hypoplasia and semen abnormalities. J. Urol. 122: 36-39.

Ginsburg, M., Snow, M.H., and McLaren, A. 1990. Primordial germ cells in the mouse embryo during gastrulation. Development 110: 521-528.

Giuili, G., Shen, W.H., and Ingraham, H.A. 1997. The nuclear receptor SF-1 mediates sexually dimorphic expression of Müllerian Inhibiting Substance, in vivo. Development 124: $1799-1807$.

Gouedard, L., Chen, Y.G., Thevenet, L., Racine, C., Borie, S., Lamarre, I., Josso, N., Massague, J., and di Clemente, N. 2000. Engagement of bone morphogenetic protein type IB receptor and smadl signaling by anti-Müullerian hormone and its type II receptor. J. Biol. Chem. 275: 27973-27978.

Greene, R.R., Burrill, N.W., and Ivy, A.C. 1942. Experimental intersexuality: The effects of estrogens on the antenatal sexual development of the rat. Am. J. Anat. 67: 305-345.

Griffin, J.E. and Wilson, J.D. 1980. The syndromes of androgen resistance. N. Engl. J. Med. 302: 198-209.

Grocock, C.A., Charlton, H.M., and Pike, M.C. 1988. Role of the fetal pituitary in cryptorchidism induced by exogenous maternal oestrogen during pregnancy in mice. J. Reprod. Fertil. 83: 295-300.

Grosschedl, R., Giese, K., and Pagel, J. 1994. HMG domain proteins: Architectural elements in the assembly of nucleoprotein structures. Trends Genet. 10: 94-100.

Heyns, C.F. and de Klerk, D.P. 1985. The gubernaculum during testicular descent in the pig fetus. J. Urol. 133: 694-699.

Hsieh-Li, H.M., Witte, D.P., Weinstein, M., Branford, W., Li, H., Small, K., and Potter, S.S. 1995. Hoxa 11 structure, extensive antisense transcription, and function in male and female fertility. Development 121: 1373-1385.

Hsu, S.Y. 1999. Cloning of two novel mammalian paralogs of relaxin/insulin family proteins and their expression in testis and kidney. Mol. Endocrinol. 13: 2163-2174.

Hunter, J. 1762. Observation on the state of the testis, and on hernia congenita. In Medical Commentaries, pp. 75-90.

Husmann, D.A. and Levy, J.B. 1995. Current concepts in the pathophysiology of testicular undescent. Urology 46: 267276.

Husmann, D.A. and McPhaul, M.J. 1991. Time-specific androgen blockade with flutamide inhibits testicular descent in the rat. Endocrinology 129: 1409-1416.

Hutson, J.M. 1985. A biphasic model for the hormonal control of testicular descent. Lancet 2: 419-421.

. 1986. Testicular feminization: A model for testicular descent in mice and men. J. Pediatr. Surg. 21: 195-198.

Hutson, J.M., Baker, M., Terada, M., Zhou, B., and Paxton, G. 1994. Hormonal control of testicular descent and the cause of cryptorchidism. Reprod. Fertil. Dev. 6: 151-156.

Ikeda, Y., Shen, W.H., Ingraham, H.A., and Parker, K.L. 1994. Developmental expression of mouse steroidogenic factor-1, an essential regulator of the steroid hydroxylases. Mol. Endocrinol. 8: 654-662.

Imbeaud, S., Belville, C., Messika-Zeitoun, L., Rey, R., di Clemente, N., Josso, N., and Picard, J.Y. 1996. A 27 base-pair deletion of the anti-Müllerian type II receptor gene is the most common cause of the persistent Müllerian duct syndrome. Hum. Mol. Genet. 5: 1269-1277.

Josso, N. and di Clemente, N. 1997. Serine/threonine kinase receptors and ligands. Curr. Opin. Genet. Dev. 7: 371-377.

Jost, A. 1947. Recherches sur la différentiation de l'embryon de lapin III. Arch. Anat. Microscop. Morphol. Exp. 36: 271-315.

. 1953. Problems of fetal endocrinology: The gonadal and hypophyseal hormones. Recent Prog. Horm. Res. 8: 379-418.

Kasik, J., Muglia, L., Stephan, D.A., and Menon, R.K. 2000. Identification, chromosomal mapping, and partial characterization of mouse Ins16: A new member of the insulin family. Endocrinology 141: 458-461.

Kelly-Spratt, K.S., Klesse, L.J., Merenmies, J., and Parada, L.F. 1999. A TrkB/insulin receptor-related receptor chimeric receptor induces PC12 cell differentiation and exhibits pro- 
longed activation of mitogen-activated protein kinase. Cell Growth Differ. 10: 805-812.

Koopman, P. 1999. Sry and Sox9: Mammalian testis-determining genes. Cell. Mol. Life Sci. 55: 839-856.

Koopman, P., Gubbay, J., Vivian, N., Goodfellow, P., and LovellBadge, R. 1991. Male development of chromosomally female mice transgenic for Sry. Nature 351: 117-121.

Kreidberg, J.A., Sariola, H., Loring, J.M., Maeda, M., Pelletier, J., Housman, D., and Jaenisch, R. 1993. WT-1 is required for early kidney development. Cell 74: 679-691.

Lane, A.H. and Donahoe, P.K. 1998. New insights into Müllerian inhibiting substance and its mechanism of action. $J$. Endocrinol. 158: 1-6.

Lok, S., Johnston, D.S., Conklin, D., Lofton-Day, C.E., Adams, R.L., Jelmberg, A.C., Whitmore, T.E., Schrader, S., Griswold, M.D., and Jaspers, S.R. 2000. Identification of INSL6, a new member of the insulin family that is expressed in the testis of the human and rat. Biol. Reprod. 62: 1593-1599.

Lyet, L., Louis, F., Forest, M.G., Josso, N., Behringer, R.R., and Vigier, B. 1995. Ontogeny of reproductive abnormalities induced by deregulation of anti-mullerian hormone expression in transgenic mice. Biol. Reprod. 52: 444-454.

Lyon, M.F. and Hawkes, S.G. 1970. X-linked gene for testicular feminization in the mouse. Nature 227: 1217-1219.

Mahendroo, M.S., Cala, K.M., Landrum, D.P., and Russell, D.W. 1997. Fetal death in mice lacking $5 \alpha$-reductase type 1 caused by estrogen excess. Mol. Endocrinol. 11: 917-927.

Mishina, Y., Rey, R., Finegold, M.J., Matzuk, M.M., Josso, N., Cate, R.L., and Behringer, R.R. 1996. Genetic analysis of the Müllerian-inhibiting substance signal transduction pathway in mammalian sexual differentiation. Genes \& Dev. 10: $2577-2587$.

Mishina, Y., Whitworth, D.J., Racine, C., and Behringer, R.R. 1999. High specificity of Müllerian-inhibiting substance signaling in vivo. Endocrinology 140: 2084-2088.

Munsterberg, A. and Lovell-Badge, R. 1991. Expression of the mouse anti-Müllerian hormone gene suggests a role in both male and female sexual differentiation. Development 113: 613-624.

Muscatelli, F., Strom, T.M., Walker, A.P., Zanaria, E., Recan, D., Meindl, A., Bardoni, B., Guioli, S., Zehetner, G., Rabl, W., and et al. 1994. Mutations in the DAX-1 gene give rise to both X-linked adrenal hypoplasia congenita and hypogonadotropic hypogonadism. Nature 372: 672-676.

Nachtigal, M.W., Hirokawa, Y., Enyeart-VanHouten, D.L., Flanagan, J.N., Hammer, G.D., and Ingraham, H.A. 1998. Wilms' tumor 1 and Dax-1 modulate the orphan nuclear receptor SF-1 in sex-specific gene expression. Cell 93: 445454.

Nef, S. and Parada, L.F. 1999. Cryptorchidism in mice mutant for Ins13. Nat. Genet. 22: 295-299.

Nef, S., Shipman, T., and Parada, L.F. 2000. A molecular basis for estrogen-induced cryptorchidism. Dev. Biol. 224: 354-361.

Ogawa, S., Lubahn, D.B., Korach, K.S., and Pfaff, D.W. 1997. Behavioral effects of estrogen receptor gene disruption in male mice. Proc. Nat1. Acad. Sci. 94: 1476-1481.

Palmer, S.J. and Burgoyne, P.S. 1991. In situ analysis of fetal, prepuberal and adult XX--- XY chimaeric mouse testes: Sertoli cells are predominantly, but not exclusively, XY. Development 112: 265-268.

Parker, K.L. 1998. The roles of steroidogenic factor 1 in endocrine development and function. Mol. Cell. Endocrinol. 140: 59-63.

Parker, K.L. and Schimmer, B.P. 1998. Ahch and the feminine mystique. Nat. Genet. 20: 318-319.
Pusch, W., Balvers, M., and Ivell, R. 1996. Molecular cloning and expression of the relaxin-like factor from the mouse testis. Endocrinology 137: 3009-3013.

Racine, C., Rey, R., Forest, M.G., Louis, F., Ferre, A., Huhtaniemi, I., Josso, N., and di Clemente, N. 1998. Receptors for anti-Müllerian hormone on Leydig cells are responsible for its effects on steroidogenesis and cell differentiation. Proc. Nat1. Acad. Sci. 95: 594-599.

Radovick, S., Wray, S., Lee, E., Nicols, D.K., Nakayama, Y., Weintraub, B.D., Westphal, H., Cutler Jr., G.B., and Wondisford, F.E. 1991. Migratory arrest of gonadotropin-releasing hormone neurons in transgenic mice. Proc. Natl. Acad. Sci. 88: 3402-3406.

Raymond, C.S., Shamu, C.E., Shen, M.M., Seifert, K.J., Hirsch, B., Hodgkin, J., and Zarkower, D. 1998. Evidence for evolutionary conservation of sex-determining genes. Nature 391: 691-695.

Raymond, C.S., Kettlewell, J.R., Hirsch, B., Bardwell, V.J., and Zarkower, D. 1999. Expression of Dmrt1 in the genital ridge of mouse and chicken embryos suggests a role in vertebrate sexual development. Dev. Biol. 215: 208-220.

Raymond, C.S., Murphy, M.W., O'Sullivan, M.G., Bardwell, V.J., and Zarkower, D. 2000. Dmrt1, a gene related to worm and fly sexual regulators, is required for mammalian testis differentiation. Genes \& Dev. 14: 2587-2595.

Rey, R. and Picard, J.Y. 1998. Embryology and endocrinology of genital development. Bailliere's Clin. Endocrinol. Metabol. 12: $17-33$.

Rijli, F.M., Matyas, R., Pellegrini, M., Dierich, A., Gruss, P., Dolle, P., and Chambon, P. 1995. Cryptorchidism and homeotic transformations of spinal nerves and vertebrae in Hoxa-10 mutant mice. Proc. Natl. Acad. Sci. 92: 8185-8189.

Roberts, L.M., Hirokawa, Y., Nachtigal, M.W., and Ingraham, H.A. 1999a. Paracrine-mediated apoptosis in reproductive tract development. Dev. Biol. 208: 110-122.

Roberts, L.M., Shen, J., and Ingraham, H.A. 1999b. New solutions to an ancient riddle: Defining the differences between Adam and Eve. Am. J. Hum. Genet. 65: 933-942.

Robertson, K.M., O’Donnell, L., Jones, M.E., Meachem, S.J., Boon, W.C., Fisher, C.R., Graves, K.H., McLachlan, R.I., and Simpson, E.R. 1999. Impairment of spermatogenesis in mice lacking a functional aromatase (cyp 19) gene. Proc. Nat1. Acad. Sci. 96: 7986-7991.

Rouiller-Fabre, V., Carmona, S., Merhi, R.A., Cate, R., Habert, R., and Vigier, B. 1998. Effect of anti-Müllerian hormone on Sertoli and Leydig cell functions in fetal and immature rats. Endocrinology 139: 1213-1220.

Satokata, I., Benson, G., and Maas, R. 1995. Sexually dimorphic sterility phenotypes in Hoxa10-deficient mice. Nature 374: 460-463.

Shawlot, W. and Behringer, R.R. 1995. Requirement for Lim1 in head-organizer function. Nature 374: 425-430.

Shen, W.H., Moore, C.C., Ikeda, Y., Parker, K.L., and Ingraham, H.A. 1994. Nuclear receptor steroidogenic factor 1 regulates the Müllerian inhibiting substance gene: A link to the sex determination cascade. Cell 77: 651-661.

Shier, P. and Watt, V.M. 1989. Primary structure of a putative receptor for a ligand of the insulin family. J. Biol. Chem. 264: 14605-14608.

Swain, A. and Lovell-Badge, R. 1999. Mammalian sex determination: A molecular drama. Genes \& Dev. 13: 755-767.

Swain, A., Narvaez, V., Burgoyne, P., Camerino, G., and LovellBadge, R. 1998. Dax1 antagonizes Sry action in mammalian sex determination. Nature 391: 761-767.

Teixeira, J., Fynn-Thompson, E., Payne, A.H., and Donahoe, P.K. 1999. Müllerian-inhibiting substance regulates andro- 
gen synthesis at the transcriptional level. Endocrinology 140: 4732-4738.

Thigpen, A.E., Silver, R.I., Guileyardo, J.M., Casey, M.L., McConnell, J.D., and Russell, D.W. 1993. Tissue distribution and ontogeny of steroid $5 \alpha$-reductase isozyme expression. J. Clin. Investig. 92: 903-910.

Tsafriri, A., Picard, J.Y., and Josso, N. 1988. Immunopurified anti-Müllerian hormone does not inhibit spontaneous resumption of meiosis in vitro of rat oocytes. Biol. Reprod. 38: 481-485.

Tsuji, M., Shima, H., Yonemura, C.Y., Brody, J., Donahoe, P.K., and Cunha, G.R. 1992. Effect of human recombinant Müllerian inhibiting substance on isolated epithelial and mesenchymal cells during mullerian duct regression in the rat. Endocrinology 131: 1481-1488.

Vainio, S., Heikkila, M., Kispert, A., Chin, N., and McMahon, A.P. 1999. Female development in mammals is regulated by Wnt-4 signalling. Nature 397: 405-409.

Viger, R.S., Mertineit, C., Trasler, J.M., and Nemer, M. 1998. Transcription factor GATA-4 is expressed in a sexually dimorphic pattern during mouse gonadal development and is a potent activator of the Müllerian inhibiting substance promoter. Development 125: 2665-2675.

Visser, J.H. and Heyns, C.F. 1995. Proliferation of gubernaculum cells induced by a substance of low molecular mass obtained from fetal pig testes. J. Urol. 153: 516-520.

Watanabe, K., Clarke, T.R., Lane, A.H., Wang, X., and Donahoe, P.K. 2000. Endogenous expression of Müllerian inhibiting substance in early postnatal rat sertoli cells requires multiple steroidogenic factor-1 and GATA-4-binding sites. Proc. Nat1. Acad. Sci. 97: 1624-1629.

Wensing, C.J. 1986. Testicular descent in the rat and a comparison of this process in the rat with that in the pig. Anat. Rec. 214: 154-160.

Wensing, C.J. 1988. The embryology of testicular descent. Horm. Res. 30: 144-152.

Wilson, J.D., Griffin, J.E., George, F.W., and Leshin, M. 1981. The role of gonadal steroids in sexual differentiation. Recent Prog. Horm. Res. 37: 1-39.

Yu, R.N., Ito, M., Saunders, T.L., Camper, S.A., and Jameson, J.L. 1998. Role of Ahch in gonadal development and gametogenesis. Nat. Genet. 20: 353-357.

Zanaria, E., Muscatelli, F., Bardoni, B., Strom, T.M., Guioli, S., Guo, W., Lalli, E., Moser, C., Walker, A.P., McCabe, E.R., et al. 1994. An unusual member of the nuclear hormone receptor superfamily responsible for X-linked adrenal hypoplasia congenita. Nature 372: 635-641.

Zimmermann, S., Schottler, P., Engel, W., and Adham, I.M. 1997. Mouse Leydig insulin-like (Ley I-L) gene: Structure and expression during testis and ovary development. Mol. Reprod. Dev. 47: 30-38.

Zimmermann, S., Steding, G., Emmen, J.M., Brinkmann, A.O., Nayernia, K., Holstein, A.F., Engel, W., and Adham, I.M. 1999. Targeted disruption of the Insl3 gene causes bilateral cryptorchidism. Mol. Endocrinol. 13: 681-691. 


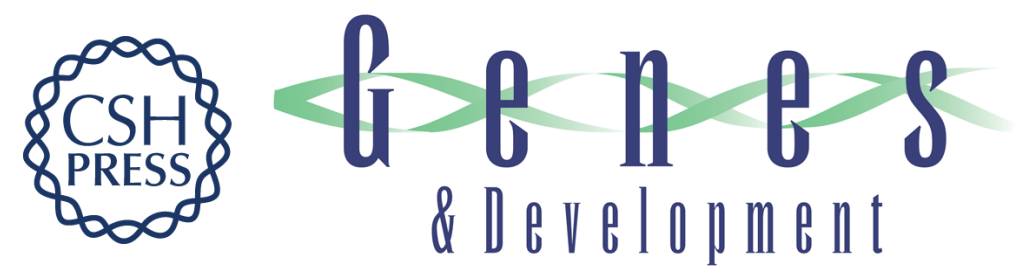

\section{Hormones in male sexual development}

Serge Nef and Luis F. Parada

Genes Dev. 2000, 14:

Access the most recent version at doi:10.1101/gad.843800

References This article cites 101 articles, 28 of which can be accessed free at: http://genesdev.cshlp.org/content/14/24/3075.full.html\#ref-list-1

License

Email Alerting Receive free email alerts when new articles cite this article - sign up in the box at the top Service right corner of the article or click here.

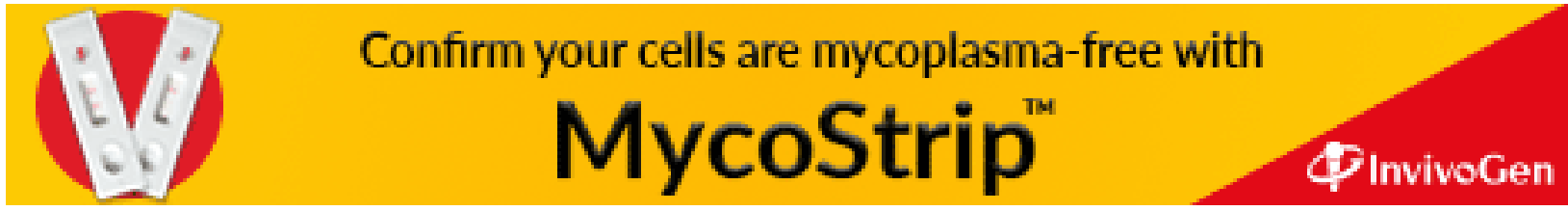

